\title{
GROWTH OF ENTEROTOXIN PRODUCING BACILLUS CEREUS IN MEAT SUBSTRATE AT $10^{\circ} \mathrm{C}$ AND $30^{\circ} \mathrm{C}$
}

\author{
Celina Mara Soares*; Dirce Yorika Kabuki, Arnaldo Yoshiteru Kuaye
}

Universidade Estadual de Campinas, Faculdade de Engenharia de Alimentos, Campinas, SP, Brasil.

Submitted: May 21, 2010; Returned to authors for corrections: July 09, 2010; Approved: June 07, 2012.

\begin{abstract}
The behaviour of enterotoxin-producing Bacillus cereus in meat was investigated by inoculating spore suspensions of five cultures into meat substrate (pH 5.8) and incubating at $10^{\circ} \mathrm{C}$ and $30^{\circ} \mathrm{C}$. The bacterial populations were evaluated after different times by plate counts in nutrient agar. All the cultures presented growth at $30^{\circ} \mathrm{C}$ with the generation time varying from 28.8 to 36.0 minutes. Three cultures also presented growth at $10^{\circ} \mathrm{C}$ with generation times between 10.16 and $28.38 \mathrm{~h}$. Considering the results, it was concluded that meat kept at abusive temperatures would be subject to development of this microorganism.
\end{abstract}

Key words: Bacillus cereus, meat, growth

\section{INTRODUCTION}

Bacillus cereus is a spore-forming organism capable of developing at a wide range of temperatures, $\mathrm{pH}$ and water activity values (24; 25; 28). This bacterium, frequently associated with food borne diseases (5), can be found in the natural environment (soil, water and air) and isolated from various foods, including meat and meat products $(15 ; 23)$.

Some of the enterotoxins produced by $B$. cereus cause food borne diarrhoea, characterised as the "diarrheic syndrome" (17; 21). This syndrome can be associated with the production of five different proteins: haemolysine BL enterotoxin (HBL) (3); non-haemolytic enterotoxin (NHE) (18); cytotoxin K (Cyt K) (17); enterotoxin T (BcET) (1) and enterotoxin FM (Ent FM) (2). The symptoms last for a period of from 12 to 24 hours and consist of abdominal pain, watery diarrhoea and nausea. It is believed that the enterotoxins are mostly produced in the small intestine of the individual (11).

Foods associated with outbreaks of $B$. cereus diarrhoea frequently include protein-rich foods (26) and researchers have emphasised the importance of the presence of the microorganism or its spores in meat and meat products for the occurrence of such outbreaks (22). Practices such as inadequate cooling after heat treatment and storage at inadequate temperatures during food processing are indicated as the main factors contributing to the spread of the microorganism in these foods (13; 22).

With the objective of investigating the growth of enterotoxin-producing B. cereus in processed meat, this study was carried out using cultures of the microorganism from different origins (food and environment) experimentally inoculated into meat substrate kept at $10^{\circ} \mathrm{C}$ and $30^{\circ} \mathrm{C}$.

*Corresponding Author. Mailing address: Universidade Estadual de Campinas, Faculdade de Engenharia de Alimentos. Brasil.; E-mail: celinasoares@hotmail.com 


\section{MATERIALS AND METHODS}

\section{Microorganism and its culture conditions}

Four cultures of enterotoxin-producing B. cereus were used in this experiment, isolated from samples collected during the processing of a meat dish in an institutional restaurant. The cultures, isolated from the ambient air (BcA), equipment surface $(\mathrm{BcE})$, seasoning $(\mathrm{BcS})$ and processed meat $(\mathrm{BcM})$, were confirmed and identified as B. cereus according to the methodology recommended by the Food and Drug Administration (9). In addition a reference diarrheic toxinproducing strain (B. cereus NCTC 11145) was used. After identification, the cultures were maintained in nutrient agar (Merck) at $4^{\circ} \mathrm{C}$. The toxigenic potential of the five cultures was confirmed using the Bacillus Diarrhoeal Enterotoxin Visual Immunoassay (kit BDE, vs MS2207 05/01; Tecra, Roseville New South Wales, Australia) according to the manufacturer's instructions.

Before use in the experiment, each of the stock $B$. cereus cultures was submitted to cell activation by inoculating into 10 $\mathrm{mL}$ BHI (Brain heart infusion broth; Difco; $\mathrm{pH} 7.4$ ) at $30^{\circ} \mathrm{C}$. This procedure was repeated successively three times, transferring one loopful of culture every $18 \mathrm{~h}$.

\section{Spore suspensions}

Spore suspensions of the cultures were prepared according to methodology described in the literature $(5 ; 7 ; 20 ; 27)$. After cell activation in BHI broth, the cultures were inoculated into Petri dishes containing sporulation medium (nutrient agar supplemented with $0.05 \%$ manganese sulphate) and incubated at $30^{\circ} \mathrm{C}$ for 4 days, when spore formation was confirmed by a microscopic examination. With the help of a Drigalski loop and the addition of $10 \mathrm{~mL}$ Milli Q water, the culture mass, with $85 \%$ or more sporulation, was aseptically removed from the surface of the culture medium. The total volume of the suspensions of each culture was transferred to a sterile tube and centrifuged at $(5000 \times \mathrm{g})\left(6^{\circ} \mathrm{C} / 20 \mathrm{~min}\right)$. The supernatant was discarded and the pellet re-suspended in Milli $\mathrm{Q}$ water and centrifuged again. This procedure was repeated five times and the resulting pellet re-suspended in Milli $\mathrm{Q}$ water and maintained at $4^{\circ} \mathrm{C}$.

Before inoculation into the meat substrate, the $B$. cereus spore suspensions were submitted to heat shock at $75^{\circ} \mathrm{C}$ for 10 min and standardised with respect to the spore concentration (approximately $10^{4}$ spores $/ \mathrm{mL}$ ). This standardisation was carried out by successive decimal dilutions in phosphate buffer (Butterfield's phosphate-buffered dilution water, $\mathrm{pH}$ 7.2), and inoculation and counting of the colony forming units (CFU) in Petri dishes containing nutrient agar, incubated at $30^{\circ} \mathrm{C}$ for 24 h. The purity of the suspensions was verified by inoculation into a medium selective for B. cereus (MYP agar; Mannitol yolk polymixin agar; Difco).

\section{Meat substrate, inoculation and counting of $B$. cereus}

Growth of the B. cereus cultures was studied in triplicate, inoculating spore suspensions into meat substrate incubated at $10^{\circ} \mathrm{C}$ and $30^{\circ} \mathrm{C}$. Approximately $1 \mathrm{~kg}$ beef (semitendinosus muscle), obtained on the local retail market, was sterilised under pressure in an autoclave $\left(111^{\circ} \mathrm{C}\right.$ to $\left.115^{\circ} \mathrm{C} / 1 \mathrm{~h}\right)$, cooled and stored at $4^{\circ} \mathrm{C}$ for about $18 \mathrm{~h}$. The $\mathrm{pH}$ of the cooked meat was determined using a pH-meter (Micronal; model B-374).

Meat samples (10 g) were weighed aseptically in sterile pouches for the stomacher (model 400; Stomacher Labsystem Circulator Bag 6141) and pre-incubated at $10^{\circ} \mathrm{C}$ or $30^{\circ} \mathrm{C}$ for about $1 \mathrm{~h}$ before inoculation. The samples were then inoculated with $1 \mathrm{~mL}$ of spore suspension (approximately $10^{4}$ spores $/ \mathrm{mL}$ ), manually homogenised for $15 \mathrm{~s}$ and incubated at $10^{\circ} \mathrm{C}$ and $30^{\circ} \mathrm{C}$.

For the experiment at $10^{\circ} \mathrm{C}$, the inoculated samples were incubated for 7 days and analysed after 0, 1, 2, 3, 4, 5, 6 and 7 days of incubation. For the experiment at $30^{\circ} \mathrm{C}$, the samples were analysed after $0,2,4,6,8,10,12$ and $24 \mathrm{~h}$ of incubation. For the bacterial count, $90 \mathrm{~mL}$ of sterile phosphate buffer were added to the samples for homogenisation in the stomacher (Stomacher 400 Circulator; Seward) at $200 \mathrm{rpm}$ for $1 \mathrm{~min}$. The B. cereus populations were determined by way of appropriate 
decimal dilutions and inoculations $(0.1 \mathrm{~mL})$ into duplicate nutrient agar plates, incubated at $35^{\circ} \mathrm{C}$ for $20-24 \mathrm{~h}$. The absence of contamination of the inoculated samples was verified by regularly using a selective medium for $B$. cereus (MYP agar; Difco). A negative control (non-inoculated sample) was used in each of the experiments to verify the absence of contaminants. These controls were analysed after the incubation period.

\section{Generation time}

The generation time $(g)$ of the microorganism in the meat substrate was calculated from the angular coefficient of the regression straight line, resulting from the mean values of the bacterial counts verified in the three repetitions of the experiments, considering the exponential bacterial growth phase. The equation described by Madigan, Martinko, and Parker (19) was used ( $g=0.301$ /angular coefficient).

\section{Statistical analysis}

The statistical analysis was carried out by calculating the means of the bacterial counts for the three repetitions with their respective standard deviations.

\section{RESULTS AND DISCUSSION}

From the results obtained in the present study it was possible to observe that the $B$. cereus spores germinated in the meat substrate at both $10^{\circ} \mathrm{C}$ and $30^{\circ} \mathrm{C}$. All the B. cereus cultures grew at $30^{\circ} \mathrm{C}$, the bacterial populations increasing about 5 logarithmic units after 12 hours incubation at this temperature (Figure 1). At $10^{\circ} \mathrm{C}$, three cultures (BcA, BcE and $\mathrm{BCS}$ ) showed growth, with a maximum increase of 4.3 logarithmic units after $168 \mathrm{~h}$ of incubation (Figure 2). In general, typical $B$. cereus strains are mesophiles, multiplying between $10^{\circ} \mathrm{C}$ and $48^{\circ} \mathrm{C}$ with an optimum range between $28^{\circ} \mathrm{C}$ and $35^{\circ} \mathrm{C}$ (10). According to the literature, at temperatures between $5^{\circ} \mathrm{C}$ and $10^{\circ} \mathrm{C}$ some psychrotrophic and mesophilic strains are capable of producing populations of up to $10^{6}$ CFU/g and of producing toxin in foods $(6 ; 8 ; 12 ; 29)$. The $\mathrm{pH}$ of the meat substrate used in this study was 5.80. Studies have affirmed that $B$. cereus is capable of growing in substrates with $\mathrm{pH}$ values between 4.3 and 9.0 (16).

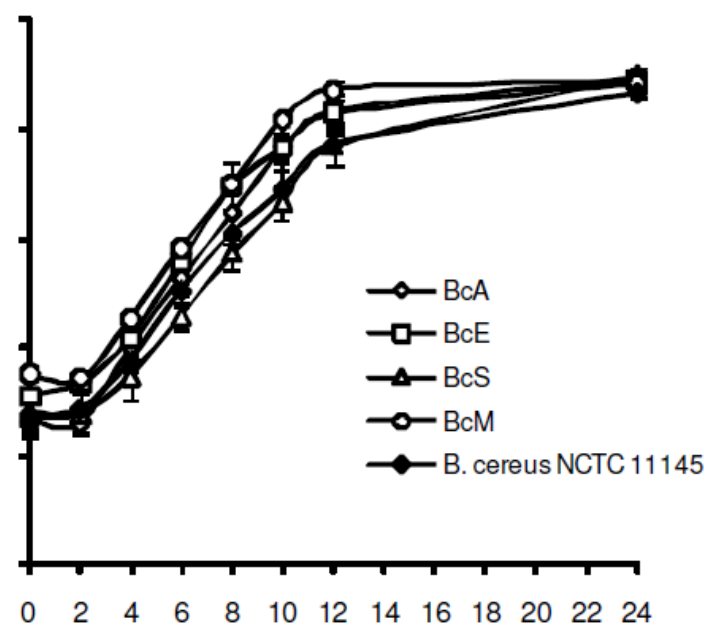

Figure 1. Growth of B. cereus in meat substrate at $30^{\circ} \mathrm{C}$. The symbols represent the means ( \pm standard deviation) of the three repetitions of each experiment. The standard deviation bars do not appear when the symbols are greater than the values of the standard deviation.

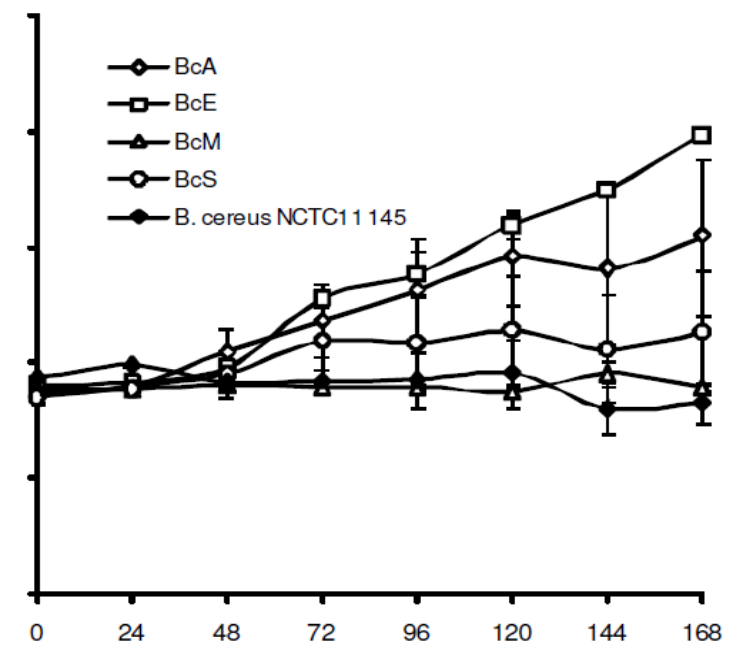

Figure 2. Growth of B. cereus in meat substrate at $10^{\circ} \mathrm{C}$. The symbols represent the means ( \pm standard deviation) of the three repetitions of each experiment. The standard deviation bars do not appear when the symbols are greater than the values of the standard deviation. 
The bacterial generation time $(g)$ at the different temperatures was calculated considering the results obtained (Table 1). At $30^{\circ} \mathrm{C}$ the generation time of the microorganism varied from 0.48 to 0.60 h. Harmon and Kautter (13) studying ready to serve foods maintained at $26^{\circ} \mathrm{C}$, and Valero et al. (27) in a study in nutrient broth at $30^{\circ} \mathrm{C}$, reported longer generation times than those obtained in the present study, between 0.72 and $0.97 \mathrm{~h}$ and between 0.69 and $1.09 \mathrm{~h}$, respectively. These variations were possibly determined by interactions between characteristics of the strain under test and extrinsic factors, such as the temperature, $\mathrm{pH}$ and substrate in which the microorganism was maintained. In studies on the behaviour of $B$. cereus, variations in the generation time, growth, toxin production and destruction of the microorganism or its spores have been reported $(4 ; 14 ; 29)$.

At $10^{\circ} \mathrm{C}$ the generation time oscillated between 10.16 and $28.38 \mathrm{~h}$ (Table 1). These values are greater than those reported in other experiments with $B$. cereus strains maintained at low temperatures in BHI broth. Benedict et al. (4) reported generation times between 5.17 and $7.04 \mathrm{~h}$ in an experiment using BHI broth incubated at $12^{\circ} \mathrm{C}$ with emetic and diarrheic toxin producing $B$. cereus strains isolated from foods, and Borge et al. (5) reported generation times between 6.7 and $13.1 \mathrm{~h}$ with enterotoxigenic isolates obtained from dairy and meat products, incubated in BHI broth at $7^{\circ} \mathrm{C}$.

Table 1. Generation time $(\mathrm{g})$ in hours, for B. cereus in meat substrate maintained at $10^{\circ} \mathrm{C}$ and $30^{\circ} \mathrm{C}$

\begin{tabular}{ccc}
\hline Culture & \multicolumn{3}{c}{ Generation time* } \\
\cline { 2 - 3 } & at $\mathbf{1 0}{ }^{\circ} \mathbf{C}$ & at $\mathbf{3 0}{ }^{\circ} \mathbf{C}$ \\
\hline BcA & $12.97(0.999)$ & $0.48(0.999)$ \\
$\mathrm{BcE}$ & $10.16(0.970)$ & $0.52(0.988)$ \\
$\mathrm{BcS}$ & $28.38(0.890)$ & $0.60(0.994)$ \\
$\mathrm{BcM}$ & ng & $0.50(0.999)$ \\
B. cereus NCTC 11145 & ng & $0.58(0.994)$ \\
\hline$*^{*}{ }^{2}\left(\mathrm{R}^{2}\right)$ & &
\end{tabular}

$* g\left(\mathrm{R}^{2}\right)$

ng: no growth observed

\section{CONCLUSION}

Protein rich foods such as meat and meat products have been associated with food borne outbreaks of diarrhoea caused by $B$. cereus. The results of the present study confirm that meat is an adequate substrate for the growth of enterotoxin producing $B$. cereus at $30^{\circ} \mathrm{C}$. In the experiment carried out at $10^{\circ} \mathrm{C}$, the growth of some of the cultures of the microorganism is relevant and should be considered in order to minimise the potential risk of spreading this microorganism in meat exposed to abusive temperatures. Spore germination and the population increase at $10^{\circ} \mathrm{C}$ emphasise the importance of the time/temperature binomial during the processing of foods.

\section{ACKNOWLEDGEMENTS}

We acknowledge the State of São Paulo Research
Foundation (FAPESP) for their financial support of this study.

\section{REFERENCES}

1. Agata, N; Otha, M; Arakawa, Y; Mori, M (1995). The bceT gene of Bacillus cereus encodes an enterotoxic protein. Microbiol. Read., 141 (4), 983-988.

2. Asano, SI; Nukumizu, Y; Bando, H; Iizuca, T; Yamamoto, T (1997). Cloning of novel enterotoxin genes from Bacillus cereus and Bacillus thuringiensis. Appl. Environ. Microbiol., 63 (3), 1054-1057.

3. Beecher, DJ; MacMillan, JD (1991). Characterization of the components of hemolysin BL from Bacillus cereus. Infec. Immun., 59 (5), 1778-1784.

4. Benedict, RC; Partridge, T; Wells, D and Buchanan, RL (1993). Bacillus cereus: aerobic growth kinetics. J. Food Prot., 56 (3), 211-214.

5. Borge, GA; Skeie, M; Sorhaug, T; Langsrud, T; Granum, PE (2001). Growth and toxin profiles of Bacillus cereus isolated from different food sources. Int. J. Food Microbiol., 69 (3), p. 237-246.

6. Christiansson, A; Naida, AS; Nilsson, I; Wadström, T and Petterson, HE (1989). Toxin production by Bacillus cereus dairy isolated in milk at low temperatures. Appl. Environ. Microbiol., 55 (10), 2595-2600.

7. Del Torre, M; Della Corte, M and Stecchini, ML (2001). Prevalence and 
behaviour of Bacillus cereus in a REPFED of Italian origin. Int. J. Food Microbiol., 63 (3), 199-207.

8. Dufrenne, J; Bijwaard, M; GiffeL, M; Beumer, R and Notermans, S. Characteristics of some psychrotrophic Bacillus cereus isolates (1995). Int. J. Food Microbiol., 27 (2/3), 175-183.

9. Food and Drug Administration (FDA). (1995). Bacteriologycal analytical manual $\left(8^{\text {th }}\right)$ Gaitherburg: FDA.

10. Gilbert, RJ. (1979). Bacillus cereus gastroenteritis. In: Riemann, H; Bryan, LF, eds. Foodborne Infections and intoxications. 2 ed. New York: Academic Press, p.495-518 .

11. Granum, PE. (1997). Bacillus cereus. In: Doyle, MP, Beuchat, LR Montville, TJ (Eds.). Food Microbiology. Fundamentals and Frontiers. Washington: ASM Press, p.327-336.

12. Guinebretière, MH; Thompson, FL; Sorokin, A; Normand, P; Dawyndt, P; Ehling-Schtultz, M; Svensson, B; Sanchis, V; Nguyen-the, C; Heyndrickx, M; De Vos, P (2008). Ecological diversification in the Bacillus cereus Group. Environ. Microbiol., 10, 851-865.

13. Harmon, SM; Kautter, DA (1991). Incidence and growth potential of Bacillus cereus in ready to serve foods. J. Food Prot., 54 (5), 372-374.

14. Johnson, KM; Nelson, CL and Busta, FF (1983). Influence of temperature on germination and growth of spores of emetic and diarrheal strains of Bacillus cereus in a broth medium and rice. J. Food Sci., 48 (1), 286-287.

15. Konuma, H; Shinagawa, K; Tokumaro, M; Onoue, Y; Konno, S; Fujino, N; Shigehisa, T; Kurata, H; Kuwabara, Y and Lopes, CAM (1988). Occurrence of Bacillus cereus in meat products, raw meat and meat products additives. J. Food Prot., 51 (4), 324-326.

16. Lund, BM (1990). Foodborne disease due to Bacillus and Clostridium species. The Lancet, 336 (8721), 982-986.

17. Lund, T; De Buyser, ML; Granum, PE (2000). A new cytotoxin from Bacillus cereus that may cause necrotic enteritis. Mol. Microbiol., 38 (2), 254- 261.

18. Lund, T; Granum, PE (1996). Characterisation of a non-haemolytic enterotoxin complex from Bacillus cereus isolated after a foodborne outbreak. FEMS Microbiol. Lett., 141 (2-3), 151-156.
19. Madigan, MT; Martinko, JM and Parker, J (1997). Brock biology of microorganisms $\left(8^{\text {th }}\right)$. New Jersey: Prentice-Hall, Inc.

20. Mahakarnchanakul, W; Beuchat, LR. (1999). Effect of shift in growth temperature on tolerance of psychrotrophic and mesophilic strains of Bacillus cereus to heat and sodium chloride. J. Food Prot., 62 (1), 57-64.

21. Mckillip, JL (2000). Prevalence and expression of enterotoxins in Bacillus cereus and other Bacillus spp., a literature review. Antonie van Leeuwenhock, 77 (4), 393-399.

22. Nortjé, GL; Voster, SM; Greebe, RP and Steyn, PL (1999). Occurrence of Bacillus cereus and Yersinia enterocolitica in South Africa retail meats. Food Microbiol., 16 (3), 213-217.

23. Pirhonen, TI; Andersson, M.A; Jaaskelainen, EL; Salkinoja-Salonen, MS; Honkanen-Buzalski, T and Johansson, TML. (2005). Biochemical and toxic diversity of Bacillus cereus in a pasta and meat dish associated with a food-poisoning case. Food Microbiol., 22 (1), 87-91

24. Reyes, JE; Bastias, JM; Gutierrez, MR and Rodriguez, MO (2007). Prevalence of Bacillus cereus in dried milk products used by Chilean school feeding program. Food Microbiol., 24 (1), 1-6.

25. Roy, A; Moktan, B and Sarkar, PK (2007). Characteristics of Bacillus cereus isolates from legume-based Indian fermented foods. Food Control, 18, 1555-1564.

26. Valero, M; Hernández-Herrero, L A; Fernández, PS and Salmerón, MC (2002). Characterization of Bacillus cereus isolates from fresh vegetables and refrigerated minimally processed foods by biochemical and physiological tests. Food Microbiol., 19 (5), 491-499.

27. Valero, M; Leontidis, S; Fernández, OS; Martínez, A and Salmerón MC (2000). Growth of Bacillus cereus in natural and acidified carrot substrates over the temperature range 5-30 ${ }^{\circ} \mathrm{C}$. Food Microbiol., 17 (6), 605-612.

28. Van Netten, P; Kramer, JM (1992). Media for detection and enumeration of Bacillus cereus in foods: a review. Int. J. Food Microbiol., 17 (2), 8599.

29. Van Netten, P; Van De Moosdijk, AP; Van Hoensel, P; Mossel, DAA.; Perales, I (1990). Psychrotrophic strains of Bacillus cereus producing enterotoxin. J. Appl. Bacteriol., 69, 73-79. 